Article

\title{
Critical Family History and Cultural Evolution: A Call for Interdisciplinary Research to Determine What Works to Replace Anger with Compassion for Social Justice
}

\author{
Pamela A. Sandoval \\ Department of Teaching, Learning and Educational Leadership, Binghamton University, 4400 Vestal \\ Parkway East, Binghamton, NY 13902, USA; sandoval@binghamton.edu
}

Received: 17 February 2020; Accepted: 28 July 2020; Published: 11 August 2020

\begin{abstract}
I use critical family history to investigate: (a) my British/Scot ancestors who engaged in slavery and have a history of oppressive treatment of indigenous peoples, and (b) my Acadian and Mi'kmaq indigenous origins. My family's conflicting history is embedded in historical hierarchies of conqueror and oppressed, as well as family dysfunction. From this history, I wonder how we can create greater positive change toward altruism and social justice? I provide literature based in cultural evolution that investigated the complex social and natural sciences that delineate our search to understand what is happening and what works to create more altruistic human behavior leading to greater social justice
\end{abstract}

Keywords: critical family history; cultural evolution; social justice; inequality

\section{Critical Family History and Cultural Evolution: A Call for Interdisciplinary Research to Determine What Works to Replace Anger with Compassion for Social Justice}

Systemic inequality and racism continue in spite of efforts to eradicate this egregious behavior. I believed we were making some progress toward valuing diversity and treating all humans with respect and dignity, but since 2016, increases in hate speech, brutality, and fascist displays of white supremacy have made me rethink our efforts and ask the question: How do we in education determine and implement best practices that work to increase the critical mass of people committed to social justice?

The human condition is complex and we need frameworks that dig deeper into understanding how we learn to adapt to changing environments, many of our own making. How we learn is not just our education system, it is how we make sense of the world and change it through trial and error, systematic science and reasoning, the stories we tell ourselves and others, as well as sheer luck. Kay and King (2020) described radical uncertainty in economics and recommended asking the question: "What is going on here"? We need to first answer that question in relation to social justice and then proceed to investigate current and continued research in the natural and social sciences to determine what actually works to increase altruism and social justice.

I ask the reader to engage with me on a personal journey with two parts: (a) my own critical history that focuses on social and family hierarchies that lead to either social dysfunction or social support, and (b) my investigations of literature on the social and natural sciences nested in cultural evolution (Wilson and Wilson 2007) to find promising research that begins to illuminate the human condition as a baseline for further complex interdisciplinary research that better determines what works.

Critical family history is a means to consider our ancestors in relation to developing greater social justice in education (Sleeter 2020, retrieved 2-15-20). For recent generations, we may learn how their circumstances shaped their beliefs and actions. Through oral history, we may learn something about 
their lives, geography, and culture. Historical records may provide facts, but may also provide a narrative written by the conqueror rather than the conquered. Genealogy typically focuses, at most, on a few hundred years of our ancestors, and we know little about who humans really are and where we came from. Recent DNA testing tells a little more of this past geography and movement, but as Reich (2018) pointed out, we are much more mixed and related than we ever imagined. Humans have been moving, inter-procreating, displacing, or destroying other societies for hundreds of thousands of years. We are all about 99.9\% African, we are all out of Africa, and all of our current obsession with our geographic origins is based on a very small amount (0.005 to 0.001$)$ of genetic difference based on mutations (Collins 2004).

To deepen this concept and to clarify how humans have changed over time, I also frame this study in the larger scale of group and cultural evolution. Wilson and Wilson (2007) have demonstrated that human evolution is not just in our genes but happens through our ability to learn and adapt in new environments and to pass this knowledge and practice to our descendants. The history of human evolution shows clear evidence that this has occurred with very little change in our actual DNA structure. For around 300,000 years, Homo sapiens were hunter gatherers and learned how to use tools, hunt, and survive using trial and error about what worked among them and in the world. Human groups typically had a hierarchy with leaders and followers and children learned from the village, including adults and older children.

Around 10,000 years ago, humans developed agriculture and then surplus agriculture that allowed for a larger social division of labor and towns. This began an advanced sense of what works for food and production, but also led to structural inequalities based on lords and serfs, with a growing number of makers and sellers of goods (Hilton 1969; Wickham 2009). The enlightenment (and similar scientific events in the Middle East, Asia, and other parts of the world) led to greater advances in knowledge that became the industrial and electronic revolution. Over time, humans advanced in both small trial and error testing and, later, large systematic science to determine what works to generally improve the conditions under which humans live their lives, with greatly increased comfort, health care, and wellbeing compared with our ancestors. Yet the industrial and technological revolution has increased socioeconomic inequalities, especially as expressed in othering people into "us and them". We still have many age-old hierarchies that cycle selfish dysfunction from the larger culture to family groups and back again. These hierarchies were evident in the colonialism of my British ancestors that engaged in slavery and engulfed both my French Acadian Metis ancestors and other indigenous peoples. These actions led to trauma across time and within families, including my own. Menakem $(2017,2020)$ suggested these traumas can and must be healed for us to move forward as a society.

Humans can and do behave in altruistic and caring ways. The good news is that evolution continues and provides the possibility for change, and as Wilson and Wilson (2007) suggested, few, if any, people actually are completely selfish or completely altruistic, but a critical mass of people can create more altruistic groups and societies. The brighter truth is that altruism provides a healthier and more positive outcome for everyone (Bowles and Gintis 2011; Christakis 2019).

Philosophers have stated for quite some time that we only know the world through our senses, with lots of back and forth on how much of the world outside of ourselves is created within (Locke [1689] 2014; Kant [1781] 1998). Lotto (2017), a neuroscientist in perception, provided clarity about this process. He suggested that from the moment of birth (or even before with touch and hearing) humans constantly check the data they receive through their senses with feedback to determine how the world works. Thus, we only know the world (including other people) from the data of our senses to the real world out there that we can never truly know. The future is always uncertain, and humans do not like uncertainty. We only know from the past to make decisions about the future. This is the basis of fear: the bear in the woods, the loss of food, and the sense of being alone and lost. Lotto suggested the opposite of fear is play and wonder, which is the basis of science. This wonder and ability creates hope and an evolutionary way for groups to change. Science is more complicated and 
elusive than it seems. Science is a systematic method that uses quantitative and qualitative methods to understand, classify, and show relationships that may be related or causal that help us live in the world. We have found ways to make our physical world more comfortable, but we have not sufficiently found ways to be more altruistic and caring to each other.

Humans also develop shared values that try to balance individual wants with the greater good of the group. Historic trial and error is a form of daily science, but is confounded by chance. Some practices work because of a correct causal connection, while others seem to work because no damage ensues. The practice then becomes a personal or cultural habit that does not really work in the way intended. For example, the parent who says, "I punish him, but he keeps doing it anyway". Humans are good at making relational guesses that often work but are not as good at doing careful systematic thinking. Kahneman (2013) calls this dichotomy as thinking fast and slow. The fast thinking can get us out of the woods when we see a bear, but it doesn't provide the careful analysis to understand how and why something works or does not work. Humans are often times bad at this systematic thought and will entrench their own false beliefs even in the face of truth. This seems to be happening a lot in our current world climate. As an example, Kahneman described a group of Wall Street financiers who received bonuses for their "outstanding" predictions in the stock market-the hot hand of choosing the "best stocks". Even after Kahneman showed them that over time, none had predictive ability above zero, they continued to believe that they had special abilities. In slightly more severe instances, we call this practice superstition or magical thinking. The good news is humans have the capacity to play, invent, and reorganize to envision new creations and new ways of doing and being. On the other hand, we need a strong understanding of what actually works and what does not. Many years ago, I came to realize in my own teaching on social justice that trying to explain stereotypes often reinforces those same stereotypes. In the past few years, taking the implicit bias test (Ito and Urland 2003) has become widespread and is meant to help people recognize when they are having a biased or fear-based response to different categories of racial, gender, or other bias. Unfortunately, this has not worked as expected. For example, the idea that training in implicit bias will alleviate those biases has not led to improvements in behavior, especially in police work (Forscher et al. 2019).

During a time of "fake news" and distorted reality, we need to determine better ways to reach those fraught with fear and resentment who are the main perpetrators of continued discrimination, even as we ourselves search for ways to be more altruistic and caring. All humans suffer in some way and all humans have fear. In our concern to alleviate the suffering of the oppressed through investigation and praxis on race/ethnicity, gender, and class, we have neglected class as a huge factor in the expression of inequality and its byproduct, fear and resentment. If we are white, we have not figured out how to really change the negative trajectory of white seething privilege and resentment that leads to individual and systemic racism. My family's conflicting history led me to ask how historical hierarchies of conqueror and oppressed are cycled from the larger social structure to the family. My hope is that this analysis of my family joined with a review that investigated the complex social and natural sciences will encourage others to search to understand what is happening and what works to create greater altruistic human behavior that leads leading to greater social justice.

\section{Method}

I used autobiographical sociology, a form of oral history and autobiography developed by Friedman (1990). He said "In sociological autobiography a sociologist probes one or more past personal experiences as a way of identifying and analyzing something sociologically relevant". (p. 60). Through this form of scholarship, a sociologist introspectively recollects and reconstructs a phenomenon or process. As a sociologist in education, I used this method to provide a way to look at my life and academic experience to analyze my family history as a way to reconsider the complexity of hierarchy as it relates to social justice. By social justice, I mean the broad range of issues including class inequality, racism, genderism, and the other unjust categorizations that divide people into us and them. When I say "we" in this text, I mean to speak to educators at all levels and disciplines. 
I searched historical records and performed DNA testing with several commercial companies, because I wanted to check a rumor that my sister was my mother, but I found no evidence of unexpected heritage or unknown relatives. I also want to make clear that my purpose in doing so was to determine biocultural kinship and cultural history (Marks 2017), not to fortify inappropriate use of genetic science. As Marks (2017) stated “ ... the social and behavioral differences between any two groups of people are far more likely to be due to the process of history than to those of microevolution." (p. 2)

I found a fairly clear history of northwest European heritage, which included British, French, Iberian, a bit of Scandinavian, and a consistent 3\% Ashkenazi Jew. The proportion of indigenous ranged from $3 \%$ to $10 \%$ with a mix of Asian. Please note that these percentages are within the very tiny proportion $(0.5 \%$ to $0.1 \%$ of actual human variation out of the $99.9 \%)$ all humans share. My mother's Acadian Metis records are in the Acadian Museum on Prince Edward Island. In addition, I joined the family tree projects, "Mothers of Acadia" and "Metis Mothers", both meant to track the first mothers of Acadia through mtDNA. Through these sources, Stephen White at the University of Moncton, New Brunswick sent me the complete genealogy, including identification of my French and indigenous ancestors, as well as the identity of my first mtDNA Mi'Kmaq grandmother. Sometime around 16,000 or so years, the woman who was my direct maternal ancestor crossed over the Bering Sea into North American and led to my eventual life.

I have less information on my father's side and rely more on his oral history, as well as from his sister and my mother. I had many discussions with my older brother before he died to verify some events that I was not sure about and years earlier had discussions with my favorite maternal aunt to verify the history my mother told. Most of the people in this story have passed away, and I have changed any names and specific locations. I use my family story and historical accounts as a case study to communicate my heritage of opposites: (a) my British/Scot ancestors who engaged in slavery and have a history of oppressive treatment of indigenous peoples, and (b) my Metis Acadian and Mi'kmaq origins. I have stronger evidence for my mother's story than for my father's story which may have as much mythology as truth, yet both accounts provide clues about how our family formed their beliefs about who we are in the world, our level of education, acceptance, and compassion towards others, and how we view and work with other people. I spend more time on my mother's history since not many people are familiar with it.

In a sense, this is a joining of two stories. Stories are important, because humans learn from the stories we tell as well as those we hear. Science tells us what is most likely real, while stories tell us what we feel and help our memories (Boyd 2009; Brakke and Houska 2015; Christiano and Neimand 2018). Stories based in our genealogy may form our understanding about social justice and prime our justification for how we interact with our more distant cousins all over the world.

\section{Critical Family History, Source of Hierarchy}

I divided the next sections into two parts: (a) my family history with my mother's family in Maritime Canada and my father's family history in the Southern United States, with descriptions of the social justice issues that impacted on us, and (b) our family disfunction that resulted from both our historical positions and its impact on our family dynamics.

In a sense, this is a story based on what Menakem (2020) called the bodies of culture, i.e., how our daily experience of having a body with our assorted experiences in a culture impacts our emotional and intellectual state. Fear, anger, hope, and all emotions are found in our bodies. He pointed out that Europeans have a long history of emotional and physical abuse among themselves, and although many came to the Americas to escape that past, they brought the pain of that history with them. This anguish of historical abuse led to deep sorrow and anger that has been displaced toward others. This hierarchy is deeply engrained in our evolutionary history. Sapolsky (2014, video link retrieved 2-14-20) studied baboons and found a hierarchy in which those at the top get most of the goodies and often vent their privilege on lower level members of the group, and this is then cascaded downward to each level of the group. Sapolsky found high levels of stress among all but the dominant males. In one 
large group he studied, the dominant males died from eating tainted meat. He described that those who were left were females and socially connected "good guys". Thereafter, the group became more equitable. As new adolescent males entered the group, they were kept in check so the entire group became more equitable and all had lower levels of stress. This happened within one generation. While we are not baboons, a question on how humans create and maintain hierarchy is an important one, especially when we ask how these hierarchies privilege group and individual beliefs in superiority and rationalize oppression. We also need more information on how humans overcome these stressful hierarchies to achieve more equitable environments.

My mother's heritage was French and Indigenous. She was born on Prince Edward Island (PEI) Canada. Her mother inherited her family farm on a beautiful bay, married twice, and had a total of nine children, my mother number five. My mother recalled aching hunger and that her family lost the farm due to economic conditions. Her father found a job in the United States when my mother was eight. As a child she was called "dirty Indian" and was punished for speaking French. When my mother was young in Canada, Acadians in the Maritime Provinces (as well as other French Canadians) were treated much like Mexican-Americans in the United States. Acadians were an admixture of European and Indigenous (mostly Mi'kmaq), who were another of the British conquered "other".

A number of historians have verified that French Acadians (of any group that colonized the Americas) had the most equalitarian relationship with indigenous people (Faragher 2005; Reid et al. 2004). The Acadians came as farmers with expertise in creating tillable fields from marsh areas. Although, settlers included a few families with women, a good number of Acadians males married Mi'kmaq women and over time intermarriage went both ways-Acadians to live with the Mi'kmaq and Mi'kmaq living among the Acadians. The relationship of the Acadians to the Mi'kmaq varied by Acadian settlement and among families (Peace 2012).

Acadia was fraught with the effects of European wars between France and England that spilled over to the new colonies (Faragher 2005; Fischer 2008). In 1710, the British conquered Acadian lands and in 1713 the French and British signed the Treaty of Utrecht that handed over Acadia to the British. For many years after, internecine French and Indian Wars continued throughout the area. The British demanded that the Acadians fight with them against the Mi'kmaq and other Algonquin tribes, but the Acadians refused for many reasons, including French and Catholic loyalties, as well as because the Mi'kmaq were us and we were them. From 1748 to 1752, as a number of Acadians moved north to evade the British, the PEI population rose from 735 to 2223 . From 1755 to 1764, during the Grand Derangement, Acadians were systematically rounded up with little or no concern about maintaining families or children, forced onto ships, and dropped at various places along the Atlantic coast and France. Later many migrated to Louisiana and became "Cajuns". Based on census records, about 14,100 Acadians lived in the region and 11,500 were deported, leaving about 2600 who avoided being captured. One of my ancestral grandmothers was among those deported and died on board a ship. Her daughter had escaped and became my next grandmother. My aunt and mother's oral history confirmed that our French Acadian ancestors hid in the woods with Mi'kmaq.

In contrast, my father's family story began with privilege and ended in poverty. He was mostly British/Scot and many of his ancestors were in North America since the revolutionary war. My father's family oral history is that one of my great-grandfathers came from a wealthy Southern family who likely owned slaves. He migrated to the Midwest, married and had two boys, one of which was my grandfather. My great-grandfather was murdered by a business partner and lost his wealth. His wife and two sons were bereft and his financial downfall led to a legacy of poverty and resentment. One son, my grandfather, at 31, married my grandmother who was 15 . He worked as a crane operator in a Great Lake's city. When my father was young, he was told and believed that he would finish high school, go to college, and become a lawyer so the family could regain their "rightful place in society".

Humans have a long history of hierarchies in and between groups. In different periods of time, as well as geographic locations, leaders have varied in the degree to which they act in self-interest versus group-interest. We also have a long history of aggression and war, often with religious assurance that 
"our" group deserves to win. The conquerors justify their oppression through a system of stereotypes that label the oppressed as deserving of poverty, disruption, removal, slavery, or death, the same stereotypes found in us and theming (Berreby 2008). Saunt (2020) clearly detailed this religious, financial, and political justification in the cruel American displacement of the Cherokee and other southern indigenous peoples. In my mother's story, the French Acadians were indeed colonizers who sought to farm and to bring Catholicism to the indigenous peoples, which included intermarriage. The Acadian experience was not typical of the general European approach to the Americas. The French, in general, were involved in the slave trade in the Caribbean and justified their approach as did Spanish and English colonizers.

This European story was exacerbated in the Southern United States. The oral history that my great-grandfather was from a wealthy Southern family set the stage for the notion to regain "our rightful place" with a strong sense of entitlement, loss, and resentment. The history of slavery is abhorrent with a distorted value system justified by biblical references. Isenberg (2016) placed the tragedy of the South in the cooptation of middle and high poverty people as benefitting from their alignment with the wealthy planters and the yeoman (Jefferson considered himself the latter). The gentry saw these poor whites as deplorables and among the lowest people, yet the gentry used stereotypes of fear to convince the poor and lower-class whites that their future was tied to white privilege and not to African peoples forced into slavery. The few whites who pointed out their similarity of class with Africans were punished and derided.

That this has continued was clear in the 1960's when President Lyndon Johnson told Bill Moyers why poor Southerners supported racist policies: "If you can convince the lowest white man he's better than the best colored man, he won't notice you're picking his pocket. Hell, give him somebody to look down on, and he'll empty his pockets for you". This intentional use of us and theming by those in power with its concomitant acceptance among the poor and struggling middle class is a strong example of how those high in the hierarchy build racial solidarity that divides and conquers to discourage class solidarity. This is still going on today.

European (and white American) beliefs in superiority became reified in the late 19th and through much of the 20th century. Through simple visual differences, Europeans constructed the notion of race (and class) and labeled people as inherently smart or dumb, good or evil. This led to a notion of "survival of the fittest", which later became known as "Social Darwinism" (Wilson and Wilson 2007). This was not as Darwin had defined human evolution. It was a social construct that led to justification for those in power to rule and it led to eugenics in the U.S., as well as in Europe. These beliefs then resulted in the scapegoating of Jews and other minority groups in Nazi Germany.

These belief systems were further instilled during the early twentieth century (Galton 1914; Terman 1919) and continued by others. Even up to the 1980's, some continued to justify this approach. For example, Jensen (1989) suggested that $80 \%$ of intelligence was inherited and the remainder came from the environment. Herrnstein and Murray (1996) and others continued to make claims that intelligence was predominantly genetically based. This belief system is seen today among white supremacists and underlies much of the continuation of Jim Crow politics in the American South and across the United States.

The notion of innate intelligence, especially as measured by IQ tests, was discredited by a number of scientists, including (Gould [1981] 1996) and Rose et al. (1984). With the advent of the human genome project and advanced research techniques, it is clear that race does not exist, and the idea that Europeans are superior is not grounded in any genetic science. Whatever humans might have as any genes associated with intelligence cannot actually be determined, because the development of the brain is completely defined by moment to moment interaction with the environment in conjunction with physical and sensed experience (Sapolsky 2017). A huge surprise was the fairly recent discovery of epigenetics, whereby, human experiences are codified into instructions that turn genes on or off (Weaver et al. 2004). 
Unfortunately, some hold on to the view that they are somehow superior through the color of their skin. Hochschild (2018) reported on white working and middle-class people in Louisiana. She described their perspective of fairness-that they have been standing in line for the goodies (higher education, jobs, health care, financial success, etc.), that they are deserving since they worked hard, and now others, who are undeserving, are jumping ahead of them. Their belief system also fell into the gross generalizations about the "other" as lazy, violent, etc. compared to "us", and that "they" should be at the end of the line where they belong. Instead of uniting with those who look different and are similar or poorer than they, they support the wealthy, hoping for the trickle-down and their place in the line.

Compos (2017) demonstrated the gap between black and white income for each income percentile and pointed to increasing inequality. It is clear that white people earn more at each level and that the gap increases as income rises. It is also clear that as the proportions rise, some African-American people have higher incomes than some whites. Across the country, the union-backed working-class jobs of many parents (or grandparents) are mostly gone, and that loss was mostly the result of management decisions to shift factories to Mexico and overseas where people were poor, would work for less wages, and were un-unionized. In spite of these overall job losses, white people still make more on average than do people from historically oppressed groups, yet many blame women and racial minorities for losses rather than the wealthy who took the jobs from them.

Our current national division is very much focused between those who cherish and appreciate different peoples and those who fear them (Vavreck et al. 2019). We also have those who choose to manipulate people's fear and anxiety to protect monied interests. Some people with large sums of money, as well as some foreign powers, are manipulating white people's pain and resentment through the use of worldwide technology, as well as other sources of influence (Wylie 2019). For their own benefit, they deftly use knowledge about how humans think and behave to convince people to act outside of their own best interest-often paid for by monied donors (Meyer 2017). These same groups have spent large sums of money to discredit current science. For example, Oreskes and Conway (2010) demonstrated how big tobacco and oil companies have influenced public opinion by discrediting the science behind the severe health hazards of using tobacco and the growing impact of environmental degradation and climate change. Similarly, at a time when biologists and geneticists have shown how all humans are related and the immense impact of the environment on the expressions of genes (Sapolsky 2017), white supremacists have spread their belief about discredited views of intelligence and superiority through social media.

Menakem $(2017,2020)$ described these hierarchical acts of injustice as a cultural fear that is passed down through generations based on the European history of inhumanity towards its own people. This class and race-based fear is deeply embedded in the human body and is ignored through our denial and intellectualizations of its existence and origins. It gives power to rationalizations about who can enforce power. In "fight or flight" it is the fight part of fear and the anger of abuse it generates. This fear and anger drives the oppressor and injures the oppressed. It is locked into our social interactions in both society and in family units.

\section{Critical Family History-Family Dysfunction}

This section takes this hierarchy down to the impact of inequality and beliefs about superiority and inferiority to the family level. It links social hierarchy with the larger structure of human stress and its impact on our ability to think critically with compassion. My family dynamics serve as one example of this phenomenon.

When my father was 16 , his father died in a crane accident. His mother told my father to quit school, get a job, take care of his younger sister, and then went west to her home state and returned a year or more later. In that time period, there were few, if any, support systems for families. When my grandmother returned, she had a new husband, and she only took her daughter. My father was not quite 18 and on his own. My father was bereft with little or no power and probably a great deal of 
fear. Kahneman and Tversky (1984) found that it is harder to lose than to win. Winning is fleeting and people's "happiness" returns to normal fairly quickly. Losses are thought about more and are not easily forgotten. The double whammy that two patriarchs died before their children reached maturity was difficult for my father. The loss of his father and desertion by his mother created a strong breeding ground for despair and resentment. His first personal loss was his dream of a college education or even high school graduation-something that was rare at the time. In the 1920 's, less than $20 \%$ of students in the United States graduated from high school (Goldin 1998).

Yet, my mother also had losses. Her family farm is now a beautiful golf and tennis club on a bay. When we visited in 1993, the owner provided a picture of the old farm house that had to be torn down. My mother cherished that picture. I saw the loss on her face as she viewed the land she lived on as a child. Even my mother's sense of loss had an edge of resentment.

My father's mother was the only grandparent I had living, and she was quite bigoted. She first tried to convince my dad not to marry my mother because she was French, Catholic, and mixed Metis. They married anyway. My sister and brother were born during the Great Depression. My younger brother and I were both surprises as my mother thought she was entering menopause after World War II. We were told we were unplanned but she loved us once she had us. We lived in a small two-bedroom apartment in a building my parents managed. My father had a job as a union, paint specialist in a local automotive factory. He was often laid off for periods of time. He drank and gambled, often leaving little or nothing for household expenses. My mother was always in debt for groceries and shopped a local market that provided credit rather than visit the cheaper chain market. She mostly managed the apartment building, including heavy labor such as taking care of the large furnace and painting apartments.

I understand from my mother that my father began drinking around age 30. He was a mean and abusive drunk. When I was five, I remember my father's physical, emotional, and sexual abuse that included inappropriate language, touching, and kissing that left me disgusted and angry. I chewed my fingernails to the quick, would not eat, and avoided being in the same room with him. I spent a lot of time hiding in the closet, in the building basement, on the stairs leading to the roof sometimes with one of my brothers. My father had several "Driving Under the Influence" arrests, lost his license for periods of time, and was put in jail. When he was sober, which was not the norm, he was very quiet, unobtrusive, and worked on projects in his basement workshop.

By the time my younger brother and I came along, we both pretty much lived in a neglectful, permissive environment. My mother was at times thoughtful and caring, but at other times neglectful about food, hygiene, and other day to day caretaking. I realized as a young adult that my mother likely lived with depression. I believe she loved my father and us but she was fearful, overwhelmed, and enabled my father's drinking.

My grandmother also drank and smoked to excess and was often angry and abusive when drunk. She said terribly bigoted things to my mother and others including my paternal cousin who married an Italian immigrant. The last time I saw my grandmother, I was around 16 . She was about 70 at that time, bedridden, drunk, and angry. Due to the fact that I knew how bigoted she was and how she treated my mother and anyone who was not Anglo-Saxon and protestant, I choose not to visit her with my Mexican-American boyfriend and later husband and daughter.

When I was five, my older sister went to Florida for a vacation and never returned. She also became a heavy drinker. She didn't drink much when I was there, so my brief stays were pleasant with a lot of time spent on the beaches. In her early 50 's, her alcohol addiction became quite serious and she lost her job as assistant buyer in a department store. She died at 59 from breast cancer that was not diagnosed until she easily broke a bone and it was clear that it had spread to her bones. She had no children. My older brother was the physical caretaker for my mother. For example, she would tell him to bring our father home from any one of several local taverns. As an adult, my brother told me this was a huge and painful burden. While I hid, my older brother often fought with our father to protect our mother. When I was about four or five, our father was looking for a fight and began beating on 
him. My brother who was about 14 or15 at the time and had been lifting weights in the basement for a year or so, knocked him flat. My brother graduated from high school at 17 and joined the Navy just to get away. He married at 19 and started an Associate Degree to become an electrician, but his wife got pregnant in his first semester. He found a job and never returned to school. He had three children, of which only one entered college, but left in the first year. He and my younger brother did not drink but did use other drugs over various periods of time.

My younger brother was the most affected by our family dysfunction. After I married and was in the hospital having my daughter, my parents came to visit and said that he had been in a motorcycle accident, had hit his head, and was in the hospital as well. After that, he was diagnosed with mental illness and it has never been clear how much was the result of his accident, our family history, any genetic predisposition to forms of mental illness, or just a combination of all these. As of this writing, I do not know if he is dead or alive, and I haven't seen or heard from him since 1993. His story is the most painful and impacted on many others including deeply on me. His story is extremely personal and is a story only he could tell.

It wasn't until I was around 35 and had a phone conversation with my father that I called him on his drinking. He said, "That didn't bother anyone". I was flummoxed. I told him about the things he had done, and I realized he had no memory of them, that he had done the worst things in blackout. Right after that, he ended up in the hospital with liver and heart problems where they told him he had to stop drinking. He did and my parents finished their lives as a happy couple-something that was quite wonderful to watch.

By the time I was 12, I decided that I would not smoke, drink, or engage in sex. I knew I had to be different than my family. Was this why I was different then my siblings? It is not that I have never failed, I certainly have made many errors and mistakes. Somehow given my own life experiences, both those accidental and those I choose, I have had better life outcomes than my parents or siblings. I was fortunate that my mother's legacy to me was a strong sense of equality that included everyone. I never heard her label people, and she was very accepting of everyone. I believe that her own sense of the pain of being "other" led her to treat others cordially and with respect.

We lived in a diverse area near one of the Great Lakes and the city's downtown area. The street I lived on was the dividing line between a sort of shabby-chic area of apartment buildings, older stately homes some used as boarding houses or flats, and churches, schools, small hotels. The other side was a large Italian community. A couple of blocks away across the river was a large African-American community. I was pretty adventurous and spent much time on the lakefront as well as wandering and playing with other kids I met in the various communities.

In third grade I read everything I could about Native American people from groups across the United States and Canada, because my mother said we had Indigenous ancestors. When I was young, there were still many western movies. I hated the typical scene where the U.S. Army would save the wagon train settlers. I tried to tell my friends that it was wrong-it was the Indians' land and people that were being threatened and killed. Then I read Ann Frank and was deeply disturbed that such a thing could have actually happened to Jewish people in Europe. When I began to understand the predicament of slavery, I realized that people's lives were heavily influenced by their circumstances and these circumstances were then often used against them. I have tried to understand my own life and the lives of others through this lens. Although I have suffered at times from my own "foot in mouth", I have tried to find what makes a difference and help us all to help ourselves and to help others.

As an educator concerned with equity, I made the connection between the notion of fixed versus growth mindset (Dweck and Molden 2017). In a fixed mindset, people believe that their ability is innate and cannot change, whereas, in a growth mindset, ability is fluid and can change with work and effort. When teachers project a fixed mindset on children or when an adult or child believes ability is innate, children are less likely to persevere in a learning environment. Similarly, Steele (2011) demonstrates that when teachers/proctors give a test and suggest ability in whatever area is stereotypical, the person performs less well. Examples include white men and physical ability, women and math, and stereotypes 
about oppressed groups. I understood why the notion of a "fixed mindset" was so deeply ingrained in American thought, especially in relation to those who have been historically oppressed. I realized that the British and United States focus on identifying ability typically through IQ tests to place children in the "right" track was a serious mistake that misled us for so many years. We inappropriately labeled and categorized children based upon single tests that were prone to misuse and were heavily based on life experiences and an ability to concentrate at the time of the test. Current cognitive science (Moore 2003; Tucker-Drob et al. 2011; Turkheimer et al. 2003) backs this more egalitarian view. Over the past 100 or more years, we have used IQ tests to inappropriately sort children, which too often results in fear of failure or learned helplessness with dire consequences for those who are labeled as "not smart", especially children from oppressed groups who have been stereotyped. Spinath et al. (2003) suggested that the notion of incremental or innate ability includes beliefs that personality is stable or changeable. I saw that many of my family members became stuck in their situation and had great difficulty changing. This began with a downward spiraling through the use of temporary sources of relief such as alcohol and drugs as forms of self-medication (Harris and Edlund 2005). Humans develop habits as shortcuts for behavior. Once a habit is established, it takes concerted effort over a period of time to change. Addictions up that ante toward change to an extreme level. This was evident when my grandmother, father, and sister used alcohol and my brothers turned to drugs.

In my teens, I accidentally discovered a much more promising future. I had dated several boys while in high school and then before my sophomore year, I met my former husband, Guy, still a good friend. His family accepted me whole-heartedly as the woman he planned to marry. I loved that they hugged me every time I visited his house. They accepted me unconditionally including his older married brother and sisters. His father had a brother who lived nearby with six children, whose oldest was just a couple of years younger than Guy. These cousins also became lifelong friends.

Guy's Mexican-American extended family saved me in ways that did not happen for my siblings. His family members were kind and focused on education. They took me into a full family that was, on the whole, warmer and safer than my family of birth. It was not that they did not have any problems. They suffered from discrimination. For example, Guy experienced "driving while Mexican", being called names on the street, with many other events and microaggressions in his life. His immediate family suffered when his father's first wife died, leaving him with two children, and then his second wife (Guy's mother) died from heart failure when Guy was 12 years of age. In that same year, a cousin his age died from a brain aneurism while Guy and friends were trying to take him home in a wagon. These events impacted his whole life-he needed and wanted a lot of stability, and I have always been more adventurous and a risk-taker. Although we did separate, we have remained life-long friends.

A truth is that when I hid a lot as a child, I became somewhat emotionally numb and put emotional feelings into a box of fictional stories. I did not realize that those were my feelings about what happened. It was a survival tactic that may have helped me think more rationally about how I wanted to live my own life. As an adult, I came to terms with the emotions I set aside and worked through them over several years. I recognized my emotions and then was able to think about my experiences with compassion for my siblings and my parents. A negative (or positive) from this is my need to fix tangled relationships and make them better, including subtle and overt racism.

Unfortunately, I had very little luck in getting my family members to stop using alcohol and other drugs, except a little when my father was in the hospital. As all humans, my parents displayed positive and negative qualities based on their own history. My mother was essentially a caring person who often went out of her way to help others. Yet, my mother spent a great deal of time in her own depression and continually excused and enabled our family dynamics and drug additions. I remember seeing fear on my mother's face but she rarely objected to the abuse we all suffered. In spite of her fear, she mostly spoke and behaved as though we did not have any problems. I still wish that I could have somehow provided a better life for her.

I was so fortunate that I had Guy's extended family that taught me so much about caring and taking the steps to a more fulfilling life, beginning in high school even as I continued to sleep at home, 
but spend almost all my time at his house. My high school grades began to improve, and after I graduated, we married and had my daughter. That he was in college when I met him, and that the cousins were also in college, made me realize I could do that too. I just kept going until I had a Ph.D. The habit of mind was that I could and I did, and I had people cheering me on.

In my own family and in other similar families, I have watched across cousins and other relatives how educational expectations dissipate as children mature. In contrast, Guy's extended family were working class, yet education was greatly encouraged. A comparison of the outcomes for both families across three generations is informative. Neither our parents nor his cousins' parents completed high school. Yet, in my family, among 19 descendants (siblings, cousins, and the next generation) five have some college education, but only two have a college degree (my daughter and I with advanced degrees). In Guy's family of 35, including cousins and their children, 13 completed some college, 13 completed college, and an additional five had advanced degrees, including three masters and two M.D. degrees. Another main difference between the families was the degree to which each celebrated educational achievement. In my family, it was mostly ignored or shrugged off. In Guy's family, each graduation was celebrated as an achievement for the whole family as "Look what we can do-you can do it too".

When I dated and later married Guy, he was embarrassed about being Mexican, called himself Spanish, and did not want to speak Spanish with me or our daughter when we took classes. I was proud of his being Mexican-American, and I was proud to have a child who had Mexican-American heritage. It took many years for him to have pride in his heritage. His cousins had a better life, because their mother lived and gave her children a strong sense that they should be educated and take pride in their heritage. Although they had hardships, they still had a sense of upward mobility-that they could achieve through education.

His extended family led me to understand the distinctions between adverse childhood experiences (ACEs) that are internal to a family (Burke-Harris 2018) versus those that are external to the family. In 1998, Felitti, Anda, Nordenberg, Williamson, Spitz, Edwards, Koss, and Marks (and the Center for Disease Control) determined correlates between a set of 10 ACEs and negative health outcomes. They studied 17,421 people who were patients at Kaiser Permanente San Diego Medical Center and found that $67 \%$ of people had at least one and $12.6 \%$ had four or more ACEs. The sample studied was $70 \%$ white and $70 \%$ with at least some college. Those with four or more ACEs were twice as likely to develop heart disease and 3.5 times as likely to develop chronic obstructive pulmonary disease than those who did not have any ACEs. The main reason for these outcomes is the chronic stress that children live with when living in dysfunctional families (Burke-Harris 2018).

My family's struggle with poverty and stress, my mother's history of being denigrated for being the "other", combined with my father's family myth of lost privilege led to resentment and anger all in a larger structure of adverse childhood experiences (our family scored 8 of 10) that are too often passed down generation after generation. Obviously, my family story, although often difficult, is not unique and is not as severe as what many people suffer in the United States or throughout the world.

Since the initial set of 10 ACEs were identified within families, it is clear that we also must consider how ACEs outside of the family can negatively affect children. These include ACEs caused by both human-made and natural disasters with human-made the more egregious. Yet, human impact is even evident when natural disasters strike because safety and health support may be unequally distributed before or after an event. This was clearly the case after Katrina in New Orleans (Dyson and Elliott 2006) and in the current case of COVID 19, in which minority families have suffered from a larger proportion of cases (Blow 2020).

Far too many children suffer from ACEs, both within and outside of the family, and include the following indicators that lead to high level of stress:

- $\quad$ The original Felitti et al. (1998) 10 Adverse Childhood Experiences (ACEs).

- Additional social ACEs, such as prejudicial behavior and bullying due to race/ethnicity, class, gender in all its forms, disability and disfigurement, and age.

- $\quad$ Poverty and scarce resources. 
- Community- and school-related stressors, which include neighborhood safety, food scarcity, peer-rejection, and homelessness.

- Human-made disasters such as war, terrorism, and ecological disruption.

- Acts of nature, such as fire, severe storms, flooding, earthquakes, and drought.

As Burke-Harris (2015) suggested, when we see a bear in the woods, we are appropriately alerted to possible danger. When the bear comes home and walks through the front door every night, children are primed to continual fear and are in heightened and continual stress. Burke-Harris has diligently promoted understanding about these ACEs in the medical community, as well as promoting ways to encourage families to pursue healthier family dynamics. When she first learned of the Felitti et al. (1998) study, she thought that everyone would jump on it and make it a part of all pediatric screenings. For many years, she promoted and implemented programs but was stymied by the lack of progress on recognizing and alleviating ACEs.

In the mid-1990's, I was part of a national group that had a yearly conference. For three consecutive years, we held sessions that broke into groups of African-American, Latino, Jewish, Lesbian, Asian, middle-class, and working-class women. Each group met, discussed their issues, and wrote their comments on poster paper to present to the full group. I attended the working-class sessions, and for two years in a row, I brought up issues of family dysfunction. Both years, when we met with the whole group, that issue was missing from our poster. At my urging in the third year, we held a session focused on family dysfunction. At that session, one of the attendees told her story of abuse and began to cry. The session ended early and attendees were very upset with the session and with me for encouraging it to happen. The irony was that after telling me how awful the session was and that we could not do it again, a number of them told me their personal stories including sexual abuse, rape, or beatings. One close African-American friend said she feared that talking about family problems would just reinforce racism. Hearing this from her, made me think hard about how we would approach this issue. I had no answer then and dropped it for many years. I also worried about what we would now call "triggering", and this continues to be a concern for anyone who has suffered adversity and is unprepared to discuss it even a small forum. Yet, the blindness about this topic still exists. At the 2019 American Educational Research Association (AERA) with 1838 sessions, only two had the key words "adverse childhood experiences", and only a very few sessions had any focus on social-emotional topics. This is a topic that needs much more work as it directly affects children in schools and cascades stress, fear, and anger across the larger community.

More recently, Mullainathan and Shafir (2013) demonstrated that scarce resources also create a form of stress that they label as a bandwidth shortage. These scarcities are found in the conditions of ACE's, especially when children live in poverty. I should note that scarcity is relative to what other people have and is exacerbated by media portrayals of wealth and leisure. Shortages of time, money, or feeling threatened impact on children's and adult's ability to think more deeply and function effectively, i.e., our ability to think analytically (Kahneman 2013). Continuous stress leads to reduced physical and mental health, reduced concentration, less ability to think rationally under pressure, and lessened ability to choose wisely.

As a society, we have not yet found ways to acknowledge and relieve these stressors handed down to us within families and across our geographic and political divisions. Menakem $(2017,2020)$ suggested we need to feel, acknowledge, and deal with the emotions, especially fear leading to withdrawal or unwarranted anger, situated in our bodies of culture in order to heal-both for oppressor and the oppressed. Nussbaum (2019) pointed out that humans have a long history of denying the body - that we are obviously animals but have provided all kinds of euphemisms and illusions to avoid confronting the reality of our lives. This denial begins with our own confusion about what is a real threat and inappropriate reactions to an illusion of threat as well as illusions of superiority. When Europeans first met indigenous peoples, including Africans, they imagined themselves as superior and saw others as lesser beings to be used. In their illusion of being made in god's image, they labeled the darker body as less and another resource to dominate. They labeled them as inferior, savage, and 
needing authority. When those with darker bodies did not comply, they were whipped, starved, and became victims of dispersal or genocide. Class-based versions of us versus them became exaggerated and deadly.

We as humans have created sets of agreed upon values. These values vary by religious (or nonreligious philosophies) and are codified sets of rules situated within cultures. These values are also codified into laws within geographic political entities. These values and rules are "ideal" and may not be practiced or may not be inclusive of all people. Our American ideal of "All men are created equal ..." included only white landed males and has become more inclusive only through protest and further legislation. We are still fighting this battle for equity. People who have historically been oppressed have every right to object and protest. White people of conscience must make greater efforts to dig deeply into our own fears and beliefs and to make a firm commitment to antiracist approaches to reach and change those white people who have attached their identity to monied interests that maintain class, race, and gender-based inequities, and who buy into an unfounded fear of those who look different. We need to figure out approaches that actually work, and these approaches may be different depending upon the degree of fear and emotional dysfunction we find in ourselves and our fear-based and greedy white cousins.

Bloom (2016) suggested that empathy is tied to our feelings of "us" and not often expanded to the "other". In addition, feelings of empathy are painful, even for the observer, and draw the observer away from helping - even helping those we consider "us" over long periods of time. Another instance stands out for me. I was on a national teacher education accreditation team. I sat next to a white teacher on the team during dinner, and we began to talk about teaching in high-need urban schools. She said she had taught at such a school but had to quit, because she could not deal with the children's lives and stories. She said she went home crying every night. My immediate thought with a bit of anger was, The kids live this, and you can't bear even hearing about it? Instead we talked about how hard it is to feel other people's pain. Bloom suggested that to be productive caregivers, we must move toward compassion that is rational and focused on helping. I saw that the teacher above was mired in feeling empathy but was unable to teach the children and gave up on them. I wonder if this distinction between distant sympathy, too close empathy, verses rational compassion is also why my colleagues became helplessly fearful of dealing with our own or other people's experiences of abuse. How do we move toward a deeper level of compassion that acts to relieve pain without reproducing it within ourselves or directing it towards others? Can we find compassion or the means to change the abuser, whether it is a child in pain bullying others, a teacher misusing authority, or a resentful white person who scapegoats others.

I do wonder how we can eradicate racial oppression without understanding the bigots-especially those who are also victims of class-based oppression. It is easy to be angry with the bigot and not with our own inability to create the altruistic change we want? This includes the broad range from the soft-core "I am not a racist", who is unaware of systemic racism, or the person who feels justified in their bigotry. I also recognize that as a teacher educator, I have failed to create sufficient lived-compassion among all of my students as they become teachers in schools. As I have indicated throughout this paper, we are not there yet, and we need new research and avenues to achieve a tipping point toward altruistic thinking and understanding.

Public education for all children is a new feature in human societies, which expanded during the industrial revolution. For more than 40 years, we as teacher educators have been asked to prepare new teachers to work in diverse settings and to ensure that all children are treated with dignity and respect. Universal education means that all members of a society are involved in the education system as students, teachers, parents, and people in surrounding communities. In spite of these efforts, children in poverty and children from historically oppressed groups still underperform and live in increasingly divided neighborhoods (Putnam 2015; Madrick 2020). When children bring their ACE fear into a classroom and demonstrate anger, depression, or other issues, they are often met with teacher anger or dismissal. 
Now that we know that adversity causes an inability to think, we can better recognize when children are acting out in fear and anger, or when stress creates a vicious circle of learned helplessness and functional inefficiency. One example to prevent this is life space crises intervention for children with disabilities, where the underlying idea is to destress or deescalate fear. The right thing to do is not to punish, but to help lead children out of fear with caring patience. Several research studies have shown that this method is successful in treating children with severe behavior disorders (Dawson 2003; Grskovic and Goetze 2005). How do we change the way too many of us react when confronting children and youth who in fear and show anger, and how do we help all of us develop better habits when dealing with our own adversity or dealing with children from adverse circumstances? We need to find ways to successfully engage all students who live in fear, anger, or depression. On another level, we need to determine effective ways to deal with adults under stress, especially when they impact others in various hierarchies.

\section{Conclusions}

Hierarchies based in selfishness are found in our workplaces, our communities, our culture, and the world. This paper based in critical family history with a focus on cultural evolution provided a few promising areas of research in the natural and social sciences that may help lead the way to better understanding of how humans behave in order to build a stronger base of class solidarity to overcome extreme levels of inequity. We do know some successful ways that help to change people's thinking, such as a focus on counter stereotypes (i.e., stories of success) rather than trying to prevent stereotypes by repeating them (Galinsky and Moskowitz 2000); stories and examples of attributes people have in common, rather than differences (Macrae et al. 1995); and making clear that current research in genetics demonstrates that race has no basis (Williams and Eberhardt 2008).

Another is a careful use of dissonance. In the 1980's, I worked as a research analyst at Alverno College in Milwaukee for two years. There, I learned from faculty and the School Sisters of Saint Francis that anger does not work to decrease bigotry, it just creates more fear that reinforces people's beliefs while it pushes them away. A shared smile, a nonoffensive joke, play, and compassion that creates dissonance in an individual's view may lead to more altruistic thinking. Dissonance theory has been used for many years to help create change in people's thinking (Festinger [1957] 1962) with more recent studies on changing beliefs about racism and social justice (Gawronski 2012). I have found this to be valid to this day, partly because it keeps the discussion on a rational level. It is clear that no one is listening when a discussion is based in anger and the discussion often ends in reinforcing already existing beliefs (Sapolsky 2017). On the other hand, we often have a right to be angry about injustice, but we must carefully think about the circumstances in which anger about injustice works. The recent Black Lives Matter peaceful protests may be one such strong example.

Educators impact on almost everyone at some point in their lives. But much work needs to be done, not only to understand human behavior both positive and negative, but to find persuasive ways that work to help people identify when they are working against their own best interest and the interest of their children. Finding ways that work is a huge challenge, given that so much worldwide wealth is in the hands of so few individuals, and many of them go to great lengths to divide and conquer to assure that humans keep doing the same thing we've been doing for the past five hundred years. Even we inadvertently play into this when we want more stuff as we watch media with the goodies held by the rich and famous, as shown with continual advertisements to buy more so that the very wealthy will have their tobacco, drug, oil, and other nonessential profit while paying many workers across the world minimum wages. We have reached the limit of human greed and it is on the backs of the worldwide poor, all children, and on us, the adults in the room. We do not have much time to help people understand that their own self-interest is not with wealthy people, it is with everyone. We need a sustainable future in which a critical mass of altruistic people builds a more equitable society. We may fail, but we have to try. 
We understand the ubiquity of class divisions, yet we have not found a way to make class, with its great inequity, a major issue in our society. We know it is there, but we have all been side-tracked by us and theming, even as many of us try so hard to eliminate ugly biases against historically oppressed peoples and against new immigrants who do not have European characteristics or culture. Burke-Harris talked about family dysfunction that cuts across race and class and must be approached as a human problem, not a problem for a specific group of people. The same is true of hierarchies and current worldwide inequities, especially in the United States. It is all of us-even misguided and fearful white people.

I end with a quote from Burke-Harris that summarizes the link between my critical family history and the link to finding what works. Burke-Harris (2018) recognized our need to ameliorate all human suffering when she said:

It is easy to get stuck on our own suffering because, naturally, it is what affects you most, but that's exactly the mentality that is killing black people, white people, and all people. It perpetuates the problem by framing it in terms of us versus them. Either we get ahead or they get ahead. That leads quickly to a fight for resources that fragments efforts to solve the same damn problem (p. 195).

Funding: This research received no external funding.

Conflicts of Interest: The author declares no conflict of interest.

\section{References}

Berreby, David. 2008. Us and Them: The Science of Identity. Chicago: University of Chicago Press.

Bloom, Paul. 2016. Against Empathy. The Case for Rational Compassion. New York: Ecco, Harper Collins.

Blow, Charles M. 2020. States Keep Failing Black People: The great racial imbalance in Covid-19's effect and the violent killings of black people are related. New York Times, May 13.

Bowles, Samuel, and Herbert Gintis. 2011. A Cooperative Species: Human Reciprocity and Its Evolution. Princeton: Princeton University Press.

Boyd, Brian. 2009. On the Origin of Stories: Evolution, Cognition, and Fiction. Cambridge: Harvard University Press. Brakke, Karen, and Jeremy Ashton Houska. 2015. Telling Stories: The Art and Science of Storytelling as an Instructional Strategy. Available online: http://teachpsych.org/ebooks/index.php (accessed on 3 January 2020).

Burke-Harris, Nadine. 2015. How Childhood Trauma Affects Health across a Lifetime. TED Talk. Available online: https://www.youtube.com/watch?v=95ovIJ3dsNk (accessed on 10 August 2017).

Burke-Harris, Nadine. 2018. The Deepest Well: Healing the Long-Term Effects of Childhood Adversity. New York: Houghton Mifflin.

Christakis, Nicholas A. 2019. Blueprint: The Evolutionary Origins of a Good Society. New York: Little Brown Spark.

Christiano, Ann, and Annie Neimand. 2018. The science of what makes people care. Stanford Social Innovations Review 16: 26-33. Available online: https://ssir.org/articles/entry/the_science_of_what_makes_people_care (accessed on 10 October 2019).

Collins, Francis S. 2004. What we do and don't know about 'race', 'ethnicity', genetics and health at the dawn of the genome era. Nature Genetics Supplement 36: S13-S15. [CrossRef] [PubMed]

Compos, Paul F. 2017. White economic privilege is alive and well. New York Times. Available online: https://www. nytimes.com/2017/07/29/opinion/sunday/black-income-white-privilege.html (accessed on 29 July 2017).

Dawson, Carol A. 2003. A study on the effectiveness of Life Space Crises Intervention for students identified with emotional disturbances. Reclaiming Children and Youth 11: 223-30.

Dweck, Carol S., and Daniel C. Molden. 2017. Mindsets: Their impact on competence, motivation, and acquisition. In Handbook of Competence and Motivation, 2nd ed. Edited by Andrew J. Elliot, Carol S. Dweck and David S. Yeager. New York: The Guilford Press, chp. 8. pp. 135-54.

Dyson, Michael Eric, and Paul Elliott. 2006. Come Hell or High Water: Hurricane Katrina and the Color of Disaster. New York: Basic Civatas Books.

Faragher, John Mack. 2005. A Great and Noble Scheme: The Tragic Story of the Expulsion of the French Acadians from Their American Homeland. New York: W. W. Norton. 
Felitti, Vincent J., Robert F. Anda, Dale Nordenberg, David F. Williamson, Alison M. Spitz, Valerie Edwards, and James S. Marks. 1998. Relationship of Childhood Abuse and Household Dysfunction to Many of the Leading Causes of Death in Adults: The Adverse Childhood Experiences (ACE) Study. American Journal of Preventive Medicine 14: 243-58. [CrossRef]

Festinger, Leon. 1962. A Theory of Cognitive Dissonance. Stanford: Stanford University Press. First published 1957. Fischer, David Hackett. 2008. Champlain's Dream. New York: Simon and Schuster.

Forscher, Patrick S., Calvin K. Lai, Jordan R. Axt, Charles R. Ebersole, Michelle Herman, Patricia G. Devine, and Brian A. Nosek. 2019. A meta-analysis of procedures to change implicit measures. Journal of Personality and Social Psychology: Attitudes and Social Cognition 117: 522-59. [CrossRef] [PubMed]

Friedman, Norman L. 1990. Autobiographical sociology. American Sociologist 21: 60-66. [CrossRef]

Galinsky, Adam D., and Gordon B. Moskowitz. 2000. Perspective taking: Decreasing stereotype expression, stereotype accessibility, and in-group favoritism. Journal of Personality and Social Psychology 78: 708-24. [CrossRef] [PubMed]

Galton, Francis. 1914. Hereditary Genius: An Inquiry into Its Laws and Consequences. New York: Macmillan.

Gawronski, Bertram. 2012. Back to the Future of Dissonance Theory: Cognitive Consistency as a Core Motive. Social Cognition 30: 652-68. [CrossRef]

Goldin, Claudia. 1998. America's Graduation from High School: The Evolution and Spread of Secondary Schooling in the United States. Harvard Library: Digital Access to Scholarship. Available online: http: //nrs.harvard.edu/urn-3:HUL.InstRepos:2664307 (accessed on 7 July 2019).

Gould, Stephen Jay. 1996. The Mismeasure of Man. New York: W. W. Norton \& Company. First published 1981.

Grskovic, Janice A., and Herbert Goetze. 2005. An evaluation of the effects of Life Space Crises Intervention on the challenging behavior of individual students. Research into Practice 13: 231-35.

Harris, Katherine M., and Mark J. Edlund. 2005. Self-medication of mental health problems: New evidence from a national survey. Health Services Research 40: 117-34. [CrossRef] [PubMed]

Herrnstein, Richard J., and Charles Murray. 1996. The Bell Curve: Intelligence and Class Structure in American Life. New York: Free Press.

Hilton, Rodney. 1969. The Decline of Serfdom in Medieval England. London and Basingstoke: Macmillan.

Hochschild, Arlie Russell. 2018. Strangers in Their Own Land. New York: The New Press.

Isenberg, Nancy. 2016. White Trash: The 400-Year Untold History of Class in American. New York: Viking.

Ito, Tiffany A., and Geoffrey R. Urland. 2003. Race and gender on the brain: Electrocortical measures of attention to the race and gender of multiple categorizable individuals. Journal of Personality and Social Psychology 85: 616. [CrossRef] [PubMed]

Jensen, Arthur R. 1989. The relationship between learning and intelligence. Learning and Individual Differences 1 : 37-62. [CrossRef]

Kahneman, Daniel. 2013. Thinking Fast and Slow. New York: Farrar, Straus, \& Giroux.

Kahneman, Daniel, and Amos Tversky. 1984. Choices, values and frames. American Psychologist 34: 341-50. [CrossRef]

Kant, Immanuel. 1998. The Critique of Pure Reason. Cambridge: Cambridge University Press. First published 1781.

Kay, John, and Mervyn King. 2020. Decision-Making beyond the Numbers: Radical Uncertainty. New York: W. W. Norton \& Company.

Locke, John. 2014. An Essay Concerning Human Understanding: With Thoughts on the Conduct of Understanding. London: Wordsworth Editions Limited. First published 1689.

Lotto, Beau. 2017. Deviate: The Science of Seeing Differently. London: Weidenfeld \& Nicolson.

Macrae, C. Neil, Galen V. Bodenhausen, and Alan B. Milne. 1995. The dissection of selection in person perception: Inhibitory processes in social stereotyping. Journal of Personality and Social Psychology 69: 397-407. [CrossRef] [PubMed]

Madrick, Jeff. 2020. Invisible Americans: The Tragic Cost of Child Poverty. New York: Alfred A. Knopf.

Marks, Jonathan. 2017. Is Science Racist? Oxford: Polity Press.

Menakem, Resmaa. 2017. My Grandmother's Hands: Racialized Trauma and the Pathway to Mending Our Hearts and Bodies. Las Vegas: Central Recovery Press.

Menakem, Resmaa. 2020. Notice the Rage: Notice the Silence. On Being with Krista Tippett. Available online: https://onbeing.org/programs/resmaa-menakem-notice-the-rage-notice-the-silence/ (accessed on 6 May 2020). 
Meyer, Jane. 2017. Dark Money: The Hidden History of the Billionaires behind the Radical Rise of the Right. New York: Anchor Books.

Moore, David S. 2003. The Dependent Gene: The Fallacy of "Nature vs. Nurture". New York: Owl Books.

Mullainathan, Sendhil, and Eldar Shafir. 2013. Scarcity: Why Having Too Little Means So Much. New York: Times Books.

Nussbaum, Martha C. 2019. The Monarchy of Fear: A Philosopher Looks at Our Political Crisis. New York: Simon and Schuster Paperbacks.

Oreskes, Naomi, and Erik M. Conway. 2010. Merchants of Doubt: How a Handful of Scientists Obscured the Truth on Issues of Tobacco Smoke to Global Warming. New York: Bloomsbury Press.

Peace, Thomas. 2012. Mi'Kmaw and Acadian neighbors: Tracing complex and variable relationships in early Eighteenth Century Mi'kma'ki. Paper presented at the Canadian Historical Association's Annual Meeting at the University of Waterloo, Waterloo, ON, Canada, May 26-30.

Putnam, Robert D. 2015. Our Kids: The American Dream in Crisis. New York: Simon \& Schuster.

Reich, David. 2018. Who We Are and How We Go Here: Ancient DNA and the New Science of the Human Past. New York: Pantheon.

Reid, John G., Maurice Basque, and Elizabeth Mancke. 2004. The Conquest of Acadia, 1710: Imperial, Colonial and Aboriginal Constructions. Toronto: University of Toronto Press.

Rose, Steven, Richard Charles Lewontin, and L. Kamin. 1984. Not in Our Genes: Biology, Ideology, and Human Nature. New York: Pantheon Books.

Sapolsky, Robert. 2014. Why Hierarchy Creates a Destructive force within the Human Psyche. Video Retrieved 2-14-20. Available online: https://www.youtube.com/watch?v=A4UMyTnlaMY (accessed on 10 July 2017).

Sapolsky, Robert M. 2017. Behave: The Biology of Humans at Our Best and Worst. New York: Penguin Random House.

Saunt, Claudio. 2020. Unworthy Republic: The Dispossession of Native Aamericans and the Road to Indian Territory. New York: W. W. Norton \& Company.

Sleeter, Christine. 2020. Retrieved from Christine Sleeter's Critical Family History Website. Available online: https://www.christinesleeter.org/critical-family-history/ (accessed on 20 July 2019).

Spinath, Birgit, Frank M. Spinath, Rainer Riemann, and Alois Angleitner. 2003. Implicit theories about personality and intelligence and their relationship to actual personality and intelligence. Personality and Individual Differences 35: 939-51. [CrossRef]

Steele, Claude M. 2011. Whistling Vivaldi: How Stereotypes Affect Us and What We Can Do. New York: W. W. Norton \& Company.

Terman, Lewis Madison. 1919. The Intelligence of School Children: How Children Differ in Ability, the Use of Mental Tests in School Grading, and the Proper Education of Exceptional Children. Boston: Houghton, Mifflin Company.

Tucker-Drob, Elliot M., Mijke Rhemtulla, K. Paige Harden, Eric Turkheimer, and David Fask. 2011. Emergence of a Gene $\times$ Socioeconomic Status Interaction on Infant Mental Ability ears. Psychological Science 22: 125-33. [CrossRef] [PubMed]

Turkheimer, Eric, Andreana Haley, Mary Waldron, Brian d'Onofrio, and Irving I. Gottesman. 2003. Socioeconomic Status Modifies Heritability of IQ in Young Children. Psychological Science 14: 623-28. [CrossRef] [PubMed]

Vavreck, Lynn, John Sides, and Chris Tausanovitch. 2019. What Is Voters Highest Priority? There's a Way to Find Out. New York Times, December 5.

Weaver, Ian C. G., Nadia Cervoni, Frances A. Champagne, Ana C. D’Alessio, Shakti Sharma, Jonathan R. Seckl, Sergiy Dymov, Moshe Szyf, and Michael J. Meaney. 2004. Epigenetic programming by maternal behavior. Nature Neuroscience 7: 847-54. [CrossRef] [PubMed]

Wickham, Chris. 2009. The Inheritance of Rome. A History of Europe from 400 to 1000. London: Penguin.

Williams, Melissa J., and Jennifer L. Eberhardt. 2008. Biological conceptions of race and the motivation to cross racial boundaries. Journal of Personality and Social Psychology 94: 1033-47. [CrossRef] [PubMed]

Wilson, David Sloan, and Edward O. Wilson. 2007. Rethinking the theoretical foundations of sociobiology. Quarterly Review of Biology 82: 327. [CrossRef] [PubMed]

Wylie, Christopher. 2019. Mindf*ck: Cambridge Analytica and the Plot to Break America. New York: Random House.

(C) 2020 by the author. Licensee MDPI, Basel, Switzerland. This article is an open access article distributed under the terms and conditions of the Creative Commons Attribution (CC BY) license (http://creativecommons.org/licenses/by/4.0/). 